\title{
HOUSING AND SANITATION-RELATED DISEASES
}

\author{
FÁbIo Nishimura *
}

\begin{abstract}
Resumo
As questões de moradia e saúde são preocupações típicas dos países em desenvolvimento, uma vez que suas consequências geralmente levam a doenças mortais. Assim, com o objetivo de melhorar a assertividade das políticas públicas, minimizar as divergências entre as ações propostas pelos diferentes estudos e contribuir para mitigar essas questões, este artigo busca compreender os impactos relativos das políticas propostas, bem como sua eficiência. Para isso, avaliamos o Programa de Arrendamento Residencial (PAR) por meio de um desenho de regressão descontínua (RDD), estratégia que é fortalecida pela realização de testes de robustez. Como resultado, verificamos que o PAR foi capaz de reduzir as mortes por doenças relacionadas ao saneamento em até $11 \%$ e que esse efeito aumenta com o tempo.
\end{abstract}

Palavras-chave: habitação, programa de arrendamento residencial, financiamento habitacional, doenças sanitárias, ddesenho de regressão descontinua

\begin{abstract}
Housing and health-related issues are typical concerns of developing countries since their consequences usually lead to deadly diseases. Hence, in order to improve the assertiveness of public policies, minimize the divergences between actions proposed by different studies and contribute to mitigate those issues, this paper seeks to understand the relative impacts of the proposed policies as well as their efficiency. Thus, this paper evaluates the Brazilian Rental Housing Program (RHP) using a regression discontinuity design (RDD) model, a strategy that is strengthened by the performance of robustness tests. As a result, we verified that RHP was able to reduce deaths from sanitation-related diseases by up to $11 \%$ and that this effect increases over time.
\end{abstract}

Keywords: housing, rental housing program, mortgage loan, sanitationrelated diseases, regression discontinuity design

JEL classification: I00, I1, I18.

DOI: http://dx.doi.org/10.11606/1980-5330/ea164754

\footnotetext{
* Graduate Program in Economics of Universidade Federal de Mato Grosso. E-mail: fabio@ufr.edu.br
} 


\section{Introduction}

Sanitation issues have always been related to the lack of structural housing conditions which, associated with the lack of planning and investment in municipalities, lead to predictable consequences and chaos. According to (Organização das Nações Unidas - ONU 2019), 30\% of the world's population (2.1 billion people) does not have access to drinking water and $60 \%$ ( 4.5 billion people) does not have access to safe sanitation. In Brazil, according to the (Instituto Brasileiro de Geografia e Estatística - IBGE 2019), 16\% of households do not have a water supply connection and $34 \%$ do not have access to basic sanitation.

In this setting of insalubrity resulting from poor sanitation conditions, we point out the occurrence of deadly parasitic and infectious diseases (Montgomery \& Elimelech 2007, Cairncross et al. 2010, Wolf et al. 2019) as the major causes of deaths related to poor housing and urban infrastructure in municipalities.

To avoid such epidemiological issues, studies indicate that broadening health education (Mendonça \& Motta 2005) and the attention to institutional and cultural care (Jiménez et al. 2019) are means to reduce fatalities. Other papers state that expanding sanitation policies is the most feasible way to reduce sanitation-related diseases (McMichael 2000, Heller 2009, Mara et al. 2010, Ekane et al. 2016).

Even though the debate on how to reduce the impact of poor sanitation externalities is heated, most papers agree that public agents should design and implement strategic plans that promote the eradication of sanitation-related diseases and fatalities (Prüss et al. 2002). However, if the necessary measures to mitigate the problems caused by the lack of basic sanitation are not taken, the number of deaths from sanitation-related diseases only tends to increase (Gleick et al. 2002, Lewin et al. 2007) and health expenses that could be avoided, such as hospital admissions, appointments and exams, end up occurring (Hutton et al. 2007).

Hence, it becomes clear that housing and sanitation-related issues are massive and a great effort is required to overcome them. However, the potential solutions are uncertain due to the number of actions that must be taken and the ignorance about their effectiveness. Therefore, we will engage in a public policy evaluation process and will test if the Brazilian federal government programs are effective in reducing sanitation-related deaths - thus stimulating responses to more assertive decisions.

The Brazilian federal government implemented several housing and sanitation policies over the years. Some of them directly affect water supply, sewage treatment, solid waste management among others. However, other programs can also affect basic sanitation indirectly, such as the Rental Housing Program (RHP).

The RHP was created in 2001 by the Brazilian Federal Government, managed by the Ministry of Cities and operated by the Federal Savings Bank. Its main objective was to mitigate the housing shortage and improve the living conditions of underhoused households. The properties covered by the RHP should be in urban areas where the basic sanitation necessary for housing either already existed or would be installed.

Several previous studies have sought to link public policies to the reduction of sanitation-related diseases and deaths; however, due to the methodol- 
ogy employed, endogeneity problems might occur and produce statistically biased results. Moreover, evaluation studies linking health and sanitation to the Rental Housing Program are virtually nonexistent, which demonstrates the contribution that this paper brings to the literature.

Given this justification, this paper seeks to verify if RHP can reduce deaths from sanitation-related diseases and to elucidate the divergences involving the implementation of the program as well as its efficiency. Seeking to attain these objectives and to innovate in this field of study, this paper brought two major contributions.

First, we treat our analyses in order to avoid endogeneity issues, which allows us to elucidate the efficiency of the program through a causal analysis. To do so, we use a fuzzy regression discontinuity design (RDD) model. This method corroborates the strategy of our research due to the existence of a cutoff point in the municipality's adherence criterion to the program in a probabilistic way - thus, we can compare specific groups that are close to this cutoff point, that is, municipalities that share similar characteristics but some are eligible to the program and some are not. In addition to using a fuzzy RDD model, we also check the robustness of our statistical model through the performance of complementary statistical tests.

The second contribution is the evaluation of the impact of RHP on deaths from sanitation-related diseases, a subject that has not been previously explored from the perspective of public policy evaluation.

After performing both main and auxiliary regressions, we verified that RHP has an indirect effect of up to $11 \%$ on the reduction of deaths from sanitation-related diseases which can be assigned to the improvements in basic sanitation infrastructure experienced by the municipalities covered by the program. We also point out that the effect persists for years after the implementation of the program.

To explore these results and other contributions, this paper is divided into five parts in addition to this introduction: in section 2, we explore the general aspects of the RHP; section 3 shows the data used in the estimations; section 4 brings the empirical strategy, that is, the regression discontinuity design model as well as all the robustness tests; and, finally, section 5 contains the results and the final considerations.

\section{The Rental Housing Program - RHP}

Brazilian housing policy, following what is done in most developing countries, seeks to minimize the ailments resulting from the imbalance around the lack of housing for the poorest sections of society.

Brazil has invested in housing policies since 1946, first through the Fundação da Casa Popular (Brazilian Social Housing Foundation) and, more recently, through the Programa Minha Casa Minha Vida (My House, My Life program). The main differences between the programs are related to form of acquisition and target. The actions implemented by the government and their effects toward the housing issue have always been the object of a constant debate among specialists. Some housing policy proposals such as the Brazilian Social Housing Foundation in 1946, the Brazilian National Housing Bank and the National Housing System in 1964, the Urbanized Areas Funding Program (PROFILURB), the Funding Program for Building, Completing or Improving 
Social Housing Units (FICAM) and the Program for the Eradication of Underhousing (PROMORAR) - all in force in the 1970s - were implemented with the purpose of meeting the housing needs of the poor. Neither the 1980s nor the 1990s were significant in terms of housing policies, worsening the already existing shortage (Nishimura et al. 2018). Given the numerous programs implemented in Brazil, it becomes clear that many of the actions were not effective - the housing shortage remains and the adjacent effects that could have been attained had the shortage been overcome, such as jobs and income multipliers, are still out of reach. However, a thorough statistical evaluation of the outcomes and impacts of such policies has rarely been carried out.

Concerned about the housing shortage and its consequences, the Brazilian Federal Government created, in 2001, the Rental Housing Program (RHP). According to the (Ministério das Cidades - MC 2018), the objectives of the program included: promoting housing supply and the improvement of existing properties, promoting the improvement of the quality of life of the households covered by the program, intervening in areas targeted by master plans, creating direct and indirect jobs, using idle public properties located in areas of housing interest, and considering the needs of the elderly and the physically disabled.

The program has the prerogative to assist households with monthly income of up to 1,800 Brazilian reals and, if the family's major income provider exerts public security activities, this limit extends to 2,400 Brazilian reals. It is worth mentioning that the program is implemented in municipalities whose population is over 100,000 inhabitants, where housing issues tend to occur more intensely.

Over time, RHP underwent several changes and re-editions according to the economic scenario. Its control was transferred to the Ministry of Cities, but the Federal Savings Bank remained in charge of its execution. In addition to these bodies, the states, the Federal District and the municipalities are also involved in identifying the locations for the implementation of the projects; indicating the households that will benefit from the program; promoting actions that facilitate and reduce the costs of project implementation such as cutting taxes, contributions and fees; providing financial resources, goods or services that are economically measurable and necessary to carry out the works and services of the enterprise. Construction and real estate management companies are also involved, executing technical and operational activities of construction and management of real estate and condominium rental agreements (Ministério das Cidades - MC 2018).

In order for tenants to have access to the resources, the Ministry of Cities presents the following process: the proposal of acquisition and execution of the project is presented to the Federal Savings Bank by the construction company; the company and the project are submitted to technical and risk analyses; a legal analysis of the property seller, the construction company, and the regularity and legality of the project documentation is carried out; the final eligibility aspect of the proposal must respect the budget of the Rental Housing Fund (RHF) for the program, per federation unit; the release of funds is made in monthly installments credited to the construction company's current account subject to compliance with the physical and financial schedule of the project; the local government identifies the households that will benefit from the program; upon project completion, the units are leased to households that meet the requirements of the program; the Federal Savings Bank selects the 
tenants through analysis of records, the calculation of gross household income and the income margin that is available to commit to the lease expenses.

It is noteworthy that, to be eligible to build properties via RHP, the municipality should meet the basic urban infrastructure criterion, that is, the new housing units should be connected to the water supply, wastewater treatment and electricity supply systems as well as to other public urban benefits and services (Bonates 2008).

The program is operated with resources from the Rental Housing Fund (RHF), created exclusively for the RHP and composed of onerous resources from the Length-of-Service Guarantee Fund (FGTS) and non-onerous resources from the FAS, FINSOCIAL, FDS and PROTECH funds and the rentability of the available RHF resources (Ministério das Cidades - MC 2018).

The program adopts the modality of leasing, that is, according to Brito (2009), the property is part of the RHF and remains as fiduciary property of the Federal Savings Bank, which is the main financing agent of the public policy, fund manager and representative of the lessor until the housing units are repaid. The leasing mechanism favors potential lawsuits in case of default. Also, the lessee has 15 years to decide on the acquisition of the property.

In order to assess the impact of RHP on social variables, (Nishimura et al. 2018) verified the positive impact of the program on the construction labor market using a regression discontinuity design model, demonstrating the efficiency of the program in having a multiplier effect on wages and jobs in the construction market. In another study, (Nishimura 2020) verified that RHP reduced infant mortality also through a regression-discontinuity analysis. The paper also observed that improvements in housing and sanitation increase the chances of survival of newborns and children under the age of 2 .

In this way, the present work seeks to confirm and advance the answers regarding the benefits of RHP, now related to health issues, and assuming that through improvements in health infrastructure, we would avoid deaths in society.

\section{Data}

The data on deaths from sanitation-related diseases were collected from the database of the IT Department of the Brazilian Unified Health System (DATASUS) for the 5,570 Brazilian municipalities in the 2000-2004 period. We chose this period because it was when the program spent the most in its early years.

In the 2010 International Classification of Diseases (ICD-10), there is no code that directly represents deaths from sanitation-related diseases. Therefore, to compose the endogenous variable, we followed (Teixeira et al. 2014) 1 .

In Table 1, we can observe that, in terms of sanitation-related deaths, the control group average is higher than the treatment group average in the 20002004 period. The control group is composed of municipalities that were not contemplated by RHP and the treated are the municipalities where the program was implemented. Such difference is of $1.1 \%$, what shows that sanitationrelated deaths occur more frequently in municipalities that do not benefit from the program. Another relevant statistical factor is the fact that there is a difference in means between the groups and its covariates, demonstrating

\footnotetext{
${ }^{1}$ The ID-10 codes used in this work are in the Annex.
} 
that there is a need for a method that considers a consistent counterfactual to verify the causal effect.

Table 1: Descriptive Statistics

\begin{tabular}{l|ccc|ccc|cc}
\hline \multirow{2}{*}{ Variável } & \multicolumn{3}{|c|}{ Controle } & \multicolumn{3}{c|}{ Tratado } & \multicolumn{2}{c}{ Diferença } \\
\cline { 2 - 9 } & N. Obs. & (Média) & (D. P.) & N. Obs. & (Média) & (D. P.) & (Diff) & (D. P.) \\
\hline Ln Deaths & 286 & 0.202 & 0.004 & 598 & 0.191 & 0.003 & $0.011^{* *}$ & 0.005 \\
Amb. Costs & 289 & 3,039 & 329 & 603 & 1,595 & 144 & $1,443^{* * *}$ & 308 \\
Hosp. Costs & 289 & 2,120 & 456 & 603 & 2,619 & 3,589 & -498 & 6,071 \\
Wages & 289 & 4,120 & 554 & 603 & 5,660 & 683 & 1,540 & 1,060 \\
\hline \multicolumn{2}{l}{ Source: The }
\end{tabular}

Source: The author, 2019.

In addition to the variable "sanitation-related deaths", we also used covariates regarding public expenditure on health: ambulatory costs, hospital costs and wages of civil servants in the health sector. These control variables were inserted in our model following (Teixeira et al. 2014, Mendonça \& Motta 2005, Zucchi et al. 2000), which state that public expenditure on health has a sharp influence on sanitation-related deaths in various age groups.

Figure 1 shows the behavior of the variables considered in our model. We can observe in quadrants (a) and (b) that the variables "hospital costs" and "ambulatory costs" behave similarly before and after the implementation of RHP (intervention); also, municipalities not covered by the program (control) spend more than the covered municipalities (treated), which can be seen in both variables. From quadrant (c), we see that public expenses with wages of civil servants in the health sector increased.

The fact that some variables present opposite behaviors and sharp observable magnitudes may affect the outcomes of the program and will be verified through specific tests for such variables.

Finally, quadrant (d) shows sanitation-related deaths, whose behavior was stable in both treated and control groups. Hence, we seek to isolate the other existing statistical effects and check if RHP was really able to reduce sanitationrelated deaths.

Furthermore, in addition to the theoretical framework that justifies the choice of the variables, we also consider the purpose of attaining a greater accuracy in the estimation and ensure more robust results following (Imbens \& Lemieux 2008). All variables were collected from the Institute of Applied Economic Research (IPEA) and from the IT Department of the Unified Health System (DATASUS), for the years 2000 to 2004.

The Residential Housing Program is the responsibility of the Ministry of Cities and Caixa Econômica Federal, and in this work, the RHP was considered in this study as a dummy that takes value 1 if the municipality benefits from the program and 0 otherwise. The data and statistical information on the RHP were collected from the Caixa Econômica Federal website.

Figure 2 shows the spatial distribution and the number of municipalities covered by the RHP. We notice a concentration of the program in eastern Brazilian states such as Pernambuco, Bahia, Minas Gerais, São Paulo, Rio de Janeiro, Paraná, and Rio Grande do Sul. In 2001, 340 municipalities were covered by the program.

Table 2 presents the number of municipalities covered by RHP in each Brazilian state, with the total number of municipalities covered in 2001 (the first year of our analysis) being 340. We point out São Paulo (91 municipal- 
Figure 1: Dependent variable (d) and the model covariates (a), (b) and (c).
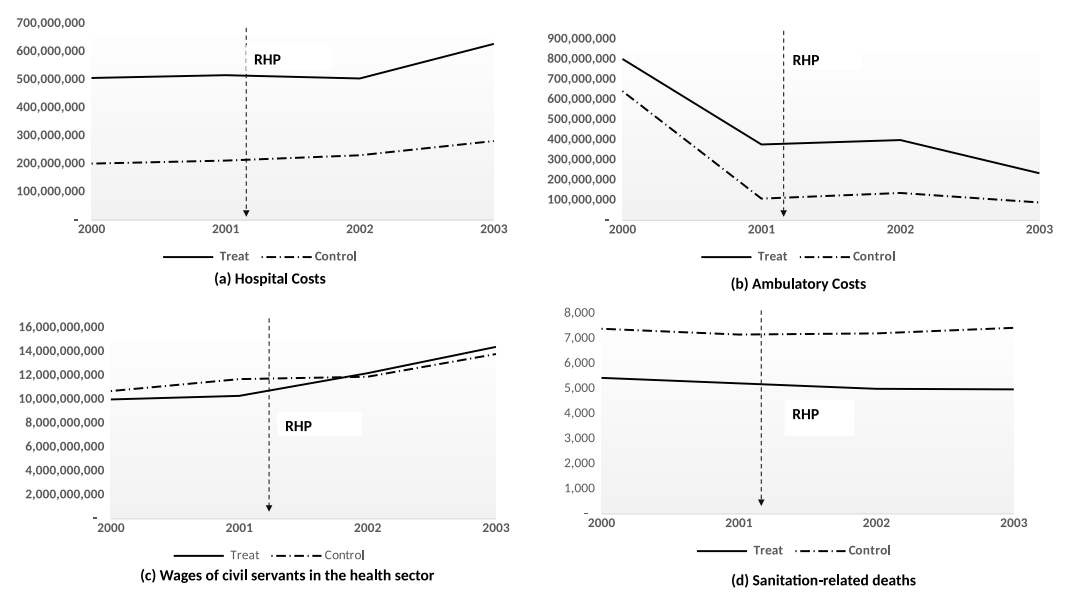

Note: Elabored by the author, 2019.

Figure 2: Number of municipalities covered by the RHP.

Quantile: PAR

$\square[1: 1](5)$

$[2: 4](8)$

$\square[5: 12](7)$

[15: 91] (7)
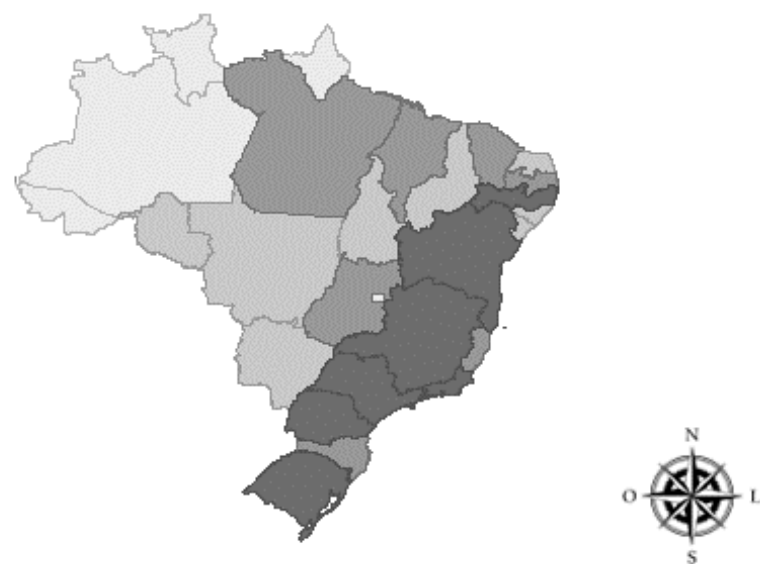

Note: Adapted from the data in Nishimura et al., 2018. 
ities), Minas Gerais (37), Rio Grande do Sul (35), Paraná (31), Rio de Janeiro (30) and Bahia (17). Together, these municipalities stand for $71 \%$ of the municipalities of the program.

Table 2: Municipalities Contemplated by RHP

\begin{tabular}{c|c|c}
\hline STATE & Municipalities with RHP & $\begin{array}{c}\text { \% in relation to the total number } \\
\text { of UF municipalities }\end{array}$ \\
\hline AC & 1 & 4.54 \\
AL & 2 & 1.87 \\
AM & 1 & 1.53 \\
AP & 1 & 5.88 \\
BA & 17 & 3.95 \\
CE & 6 & 3.09 \\
DF & 1 & 100 \\
ES & 9 & 10.84 \\
GO & 12 & 4.83 \\
MA & 8 & 3.59 \\
MG & 37 & 4.25 \\
MS & 2 & 247 \\
MT & 4 & 2.7 \\
PA & 6 & 4.16 \\
PB & 5 & 2.17 \\
PE & 15 & 7.69 \\
PI & 2 & 0.86 \\
PR & 31 & 7.56 \\
RJ & 30 & 30 \\
RN & 4 & 2.31 \\
RO & 3 & 5.55 \\
RR & 1 & 6.66 \\
RS & 35 & 6.81 \\
SC & 11 & 3.66 \\
SE & 2 & 2.63 \\
SP & 91 & 13.8 \\
TO & 2 & 1.4 \\
\hline Note: Data from the Caixa Econômica Federal, Bonates (2008) and Nishimura et \\
al. (2018). & \\
& &
\end{tabular}

Figure 3(a) shows the amount of funds allocated to the municipalities for the execution of the program, with 3.5 billion reais having been invested in the 2001-2005 period. We also observe that, in 2003, funds reached their maximum availability (around 1.113 billion reais).

In Figure 3(b), we observe that the program covered 139,109 housing units in the 2001-2005 period, reaching its maximum in 2003.

Table 3 shows the number of units funded by the RHP per Brazilian region. We observe that the Southeast and Northeast Regions are the ones that most benefit from the program. It is worth noting that the Northeast Region, despite having fewer municipalities in the treated group when compared with the South Region, has more units covered.

Hence, seeking a causal relationship between the RHP and sanitation-related deaths, we used the data and employed the empirical strategy demonstrated in the following section. 
Figure 3: (a) Amount of funds allocated to the RHP and (b) Units contracted in Brazil.

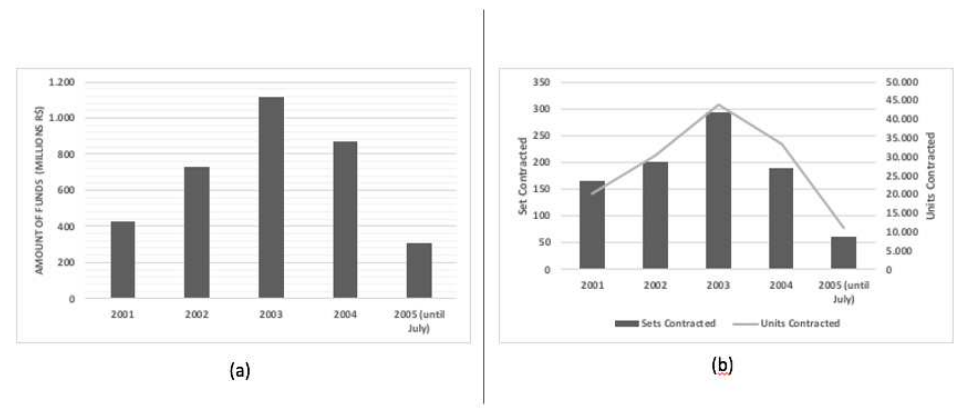

Note: Data from the Caixa Econômica Federal, Bonates (2008) and Nishimura et al. (2018).

Table 3: Number of Units Financed by RHP per Brazilian region. (R\$ Billion)

\begin{tabular}{|c|c|c|c|c|c|c|}
\hline Years & Southeast & Northeast & South & Midwest & North & Total \\
\hline 2001 & 11,280 & 5,151 & 2,398 & 864 & 622 & 20,315 \\
\hline 2002 & 16,739 & 6,297 & 3,892 & 1,677 & 1,656 & 30,261 \\
\hline 2003 & 20,562 & 12,049 & 7,093 & 3,547 & 576 & 43,827 \\
\hline 2004 & 13,177 & 10,274 & 5,068 & 4,247 & 790 & 33,556 \\
\hline Total & 61,758 & 33,771 & 18,451 & 10,335 & 3,644 & 127,959 \\
\hline
\end{tabular}

\section{Empirical Strategy}

\subsection{Regression Discontinuity Design}

One of the difficulties in analyzing the causal relationship between variables lies in isolating the statistical effects of other omitted variables, that is, the endogeneity in the model causes the estimators to be biased and the pursuit of internal validity in a quasi-experiment becomes arduous statistically.

In order to attain internal validity, we use a fuzzy regression discontinuity design (RDD) model in this study (Angrist \& Pischke 2008, Fujiwara 2015, Smith 2016).

We chose this model primarily because of the existence of an exogenous cutoff point represented by the RHP criterion of considering eligible only municipalities with more than 100,000 inhabitants. Hence, it is possible that municipalities just below the cutoff point are very similar to those just above the point, with the only difference between them being the coverage by the RHP. Thus, we have:

$$
W_{i} \neq Z_{i}=1\left\{X_{i} \geq c\right\}
$$


Where all the values of $X_{i}$ greater than or equal to c (cutoff) are in the treated group and values below $c$ are in the control group. The second important feature of our problem that made us choose the fuzzy RDD was the option of municipal managers to join the program or not. We observe this situation in Equation 1, where $X_{i} \neq Z_{i}$. This absence of obligation to adhere causes a probabilistic jump to occur before and after the cutoff point in the functions that would not occur were the policy or program mandatory. Hence, a fuzzy design is suitable when there is imperfect compliance and is defined as:

$$
\lim _{X \downarrow c} \operatorname{Pr}\left[T_{i}=1 \mid X_{i}=x\right] \neq \lim _{X \uparrow c} \operatorname{Pr}\left[T_{i}=1 \mid X_{i}=x\right]
$$

After considering the design of the model, we analyze the local effect through the following estimator:

$$
\tau_{R D D F u z z y}=\frac{\lim _{X \downarrow c} E[Y \mid X=x]-\lim _{X \uparrow} E[Y \mid X=x]}{\lim _{X \downarrow_{c}} E[W \mid X=x]-\lim _{X \uparrow c} E[W \mid X=x]}
$$

Thus,

$$
\tau_{R D D F u z z y}=E\left[Y_{i}(1)-Y_{i}(0) \mid \text { complier }, X_{i}=c\right]
$$

After the regression design is determined, we will verify the statistical consistency of our data in the presence of manipulation issues close to the cutoff point.

\subsection{Manipulation Testing Extracted from Nishimura et al. (2018).}

Before applying the empirical strategy, we must analyze the criterion imposed by the program, where municipalities must have more than 100,000 inhabitants in order to be eligible. This numerical imposition creates room for discussion on the issue of counting the population of municipalities, which has also been addressed by (Monasterio 2013). Municipality managers interested in benefiting from RHP may attempt to manipulate population information in order to be covered by the program. To test this hypothesis, we used the strategy presented in (Calonico et al. 2017) (CJM hereafter) named Manipulation Test and based, on the density of the discontinuity. According to CJM, to implement a manipulation test the researcher should estimate the density of units near the cutoff point and carry out a hypothesis test on the density of the discontinuity.

According to $\mathrm{CJM}^{2}$, we assume that $X_{1}, X_{2}, \ldots, X_{n}$ is a random sample of size $\mathrm{n}$ of the random variable $\mathrm{X}$ with cumulative distribution function (cdf) and probability density function (pdf) given by $F(x)$ and $f(x)$, respectively. The random variable $X_{i}$ stands for the score, index or variable of analysis of unit i in the sample. Each unit is assigned to the control or treatment, depending on the index $x$. In this case, the assignment of control or treatment is given by:

Unit $i$ assigned to the control group if $X_{i}<\bar{x}$

Unit $i$ assigned to the treatment group if $X_{i} \geq \bar{x}$.

\footnotetext{
${ }^{2}$ Formal test according to (Calonico et al. 2017).
} 
Where the cutoff point $\bar{x}$ is known and we have listed enough observations for each group. A manipulation test in this context is a hypothesis test on the continuity of the density $f($.$) in the cutoff point x. Formally, we are interested$ in the following problem:

$$
H_{0}: \lim _{x \uparrow x} f(x)=\lim _{x \downarrow x} f(x) \quad \text { vs } \quad H_{1}: \lim _{x \uparrow x} f(x) \neq \lim _{x \downarrow x} f(x)
$$

To construct a statistic for this hypothesis test, we follow CJM and estimate density $f($.) using a local polynomial density estimator based on the cdf of the observed sample. This estimator has many interesting properties, including the fact that it does not require data pre-binning, besides enabling the incorporation of constraints to the cdf, higher order derivatives of the density, leading to new manipulation tests with more powerful properties.

The class of statistics of the manipulation test implemented here can be expressed as follows:

$$
T_{p}(h)=\frac{\hat{f}_{p^{+}}(h)-\hat{f}_{p^{-}}(h)}{\hat{V}_{p}(h)}, \hat{V}_{p} 2=\hat{K}\left[\hat{f}_{p^{+}}(h)-\hat{f}_{p^{-}}(h)\right]
$$

Where $T_{p}(h) \sim N(0,1)$ means under proper assumptions and $V[$.$] is some$ consistent estimator of the amount of population $V[$.$] The parameter h$ is the bandwidth used to locate the procedures of estimation and inference near the cutoff point $\bar{x}$. The statistics may be constructed in several different ways, in particular, given a choice of bandwidth. Two main ingredients are used to construct the $t_{p}(h)$ test statistic considering: i) the local polynomial density estimators $f(h)$ and ii) the standard error corresponding to the estimator $p^{+}, p^{-}, p \hat{V}_{p}(h)$

These estimators also depend on the choice of the polynomial order $p$, the choice of the kernel function $K($.$) and the constraints imposed on the model,$ among other possibilities. The expressions of the standard errors $\hat{V}_{p}(h)$ can be based on an asymptotic plug-in or a jackknife approach, and its specific form will depend on additional constraints.

A key element is, naturally, the choice of the bandwidth $h$, which determines which observations near the cutoff point $\bar{x}$ will be used for estimation and inference. This choice may be specified by the user or estimated using the available data. The estimation allows, when possible, different bandwidth options on each side of the cutoff point $\bar{x}$. A bandwidth common to both sides of the cutoff point is always possible.

\subsection{Heterogeneous Responses and Robustness Tests}

To ensure the statistical significance of our estimators, we performed heterogenous response tests and robustness tests. The first heterogeneous response test was estimated considering specific groupings to confirm the main result of this paper, using a sample composed of municipalities whose sanitation infrastructure was changed.

For the robustness test, we analyzed the effect of the program prior to its beginning, that is, in the year 2000. In another moment, we tested using false cutoff points of 95,000 and 105,000 inhabitants. We also tested how the dependent variable behaves when covariates are included in the model. Thus, 
the robustness listed so far will only have statistical validity if their results are not of statistical significance.

Finally, we performed two more tests where we change the kernel function of the estimations (Uniform and Epanechnikov) and, as a result, we expect that the statistical significance is preserved and follow the same effect of the result found in Table 4 .

\section{Analysis of The Results}

This paper analyzes the effect that RHP has on deaths from sanitation-related diseases. To perform such an analysis, we first verify whether manipulation of the cutoff occurs because, if it does, our strategy should be reviewed, and further methodological care should be considered. In Table 4 , we observe that the results of this tests were not statistically significant (Manipulation Test $p>|t|=0.9519)$ and, therefore, we cannot reject the hypothesis that there was no cutoff manipulation, that is, we are allowed to maintain our empirical strategy and complete our results in statistical terms.

Another key point of our empirical strategy is to check the existence of any discontinuity in our cutoff; for this, Figure 4(a) illustrates the answer to this situation. It is noteworthy that there is a discontinuity exactly in the cutoff, indicating a sudden change between the treated and non-treated municipalities, that is, there is a probabilistic jump between the ones above and below the cutoff point. Thus, there is evidence that the RHP affects observations close to the cutoff. Figure 4(b) also displays a probabilistic jump in the cutoff point that shows that municipalities close to the point, especially the ones above it, experienced a decrease in sanitation-related deaths and are mainly influenced by RHP, since the other characteristics are the same as those of the municipalities below the cutoff.

From the initial effect detected in Figure 4, we move to Table 4, which shows the regressions that confirm the statistically significant negative effect of the program on deaths from sanitation-related diseases. Columns 1 and 2 present the regressions considering a linear specification with different bandwidths. In columns 5 and 6 , the specifications were quadratic, and the bandwidths were also different. It is worth noting that, in Table 4, we did not use controls, which will be approached later. Thus, the results indicated that there is a reduction in sanitation-related mortality in municipalities that benefit from the RHP, and the magnitude of this effect can reach up to $3.6 \%-4.3 \%$ at the beginning of the program, albeit not statistically significant - which is usual in health-related variables since they need a maturation time for the effect of the program to occur. However, when values for up to two years after the implementation of the program are considered, the intensity of the reduction of deaths range from $6.7 \%$ to $8.8 \%$ and are statistically significant, showing that the program is efficient in its indirect effects.

Table 5 has the same structural characteristics as Table 4; however, we changed the specification of the model by including the controls. As a result, columns $1,2,4$ and 5 confirm that there is also a statistically significant reduction of $5.6 \%$ to $11 \%$ in up to two years after the implementation of the program.

Hence, the results converge to the existence of the construction of quality housing units via RHP, exerting an impact on the reduction of sanitation- 
Figure 4: Discontinuity: Program (a) and Deaths from Sanitation-related diseases (b).

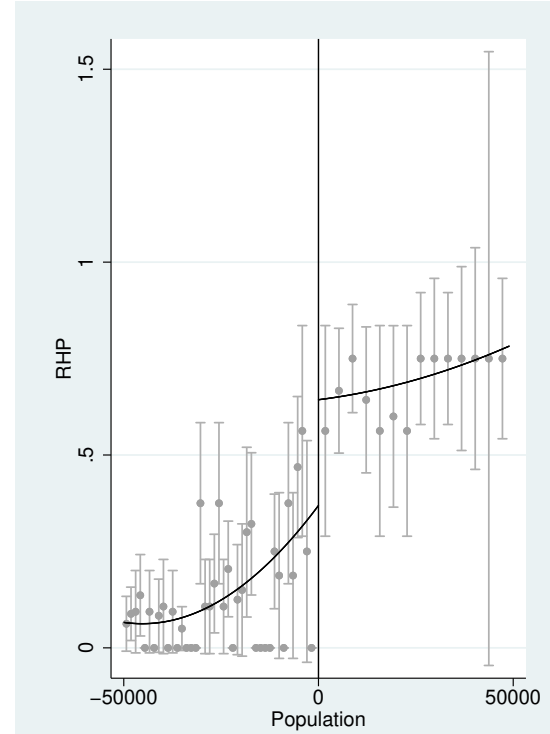

(a)

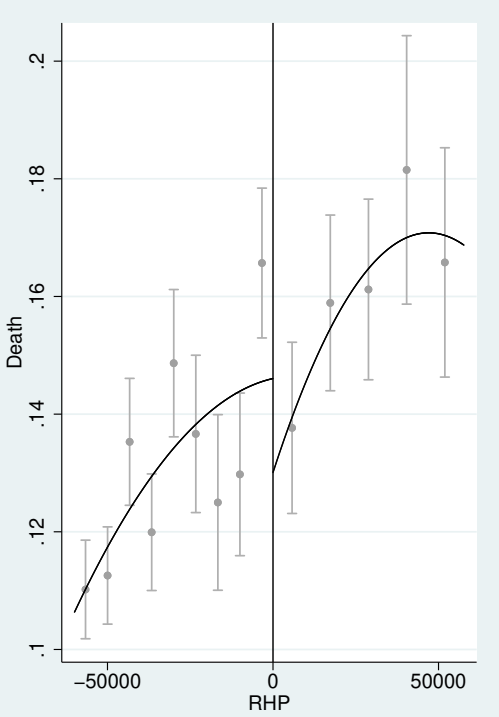

(b)

Note: The author, 2019.

Table 4: Effect of the RHP on deaths from sanitation-related diseases - without controls

\begin{tabular}{|c|c|c|c|c|c|c|}
\hline & (1) & (2) & (3) & (4) & (5) & (6) \\
\hline$R H P_{t}$ & $\begin{array}{l}-0.036 \\
(0.034)\end{array}$ & $\begin{array}{l}-0.037 \\
(0.028)\end{array}$ & $\begin{array}{l}-0.011 \\
(0.036)\end{array}$ & $\begin{array}{l}-0.043 \\
(0.038)\end{array}$ & $\begin{array}{l}-0.045 \\
(0.037)\end{array}$ & $\begin{array}{l}-0.016 \\
(0.043)\end{array}$ \\
\hline$R H P_{t+1}$ & $\begin{array}{c}-0.078^{* *} \\
(0.036)\end{array}$ & $\begin{array}{c}-0.075^{\star *} \\
(0.037)\end{array}$ & - & $\begin{array}{c}-0.086^{* *} \\
(0.043)\end{array}$ & $\begin{array}{l}-0.088^{*} \\
(0.047)\end{array}$ & - \\
\hline$R H P_{t \geq+2}$ & $\begin{array}{c}-0.067^{* *} \\
(0.027)\end{array}$ & $\begin{array}{c}-0.067^{* *} \\
(0.032)\end{array}$ & - & $\begin{array}{c}-0.072^{* *} \\
(0.034)\end{array}$ & $\begin{array}{c}-0.077^{* *} \\
(0.037)\end{array}$ & - \\
\hline $\begin{array}{l}\text { Specification } \\
\text { Bandwidth } \\
\text { Manip. Test } p>|t|\end{array}$ & $\begin{array}{c}\text { Linear } \\
\text { msecomb2 } \\
0.9519\end{array}$ & $\begin{array}{l}\text { Linear } \\
\text { msetwo }\end{array}$ & $\begin{array}{c}\text { Linear } \\
\text { Msetwo }\end{array}$ & $\begin{array}{c}\text { Quad. } \\
\text { msecomb2 }\end{array}$ & $\begin{array}{l}\text { Quad. } \\
\text { msetwo }\end{array}$ & $\begin{array}{l}\text { Quad. } \\
\text { msetwo }\end{array}$ \\
\hline N. Obs. & 1,135 & 1,135 & 2,663 & 2,673 & 2,673 & 2,663 \\
\hline
\end{tabular}

Note: Dependent variable: Ln Sanitation-related deaths. All specifications use a triangular kernel function. RHP estimates the discontinuity in municipalities right above the cutoff point $\left(100,000\right.$ inhabitants). Robust standard errors are in parentheses. ${ }^{* *}=\mathrm{p}<0.01$, $^{* *}=\mathrm{p}$ $<0.05$, and $^{*}=\mathrm{p}<0.1$. 
Table 5: Effect of the RHP on deaths from sanitation-related diseases - with controls.

\begin{tabular}{|c|c|c|c|c|c|c|}
\hline & (1) & (2) & (3) & (4) & (5) & (6) \\
\hline$\overline{R H P_{t}}$ & $\begin{array}{l}-0.034 \\
(0.030)\end{array}$ & $\begin{array}{l}-0.037 \\
(0.034)\end{array}$ & $\begin{array}{c}-0.008 \\
(0.036)\end{array}$ & $\begin{array}{l}-0.039 \\
(0.042)\end{array}$ & $\begin{array}{l}-0.019 \\
(0.045)\end{array}$ & $\begin{array}{l}-0.004 \\
(0.064)\end{array}$ \\
\hline$R H P_{t+1}$ & $\begin{array}{c}-0.095^{\star *} \\
(0.04)\end{array}$ & $\begin{array}{c}-0.091^{* *} \\
(0.047)\end{array}$ & - & $\begin{array}{c}-0.103^{* *} \\
(0.046)\end{array}$ & $\begin{array}{c}-0.110^{* *} \\
(0.054)\end{array}$ & - \\
\hline$R H P_{t \geq+2}$ & $\begin{array}{l}-0.062^{*} \\
(0.034)\end{array}$ & $\begin{array}{c}-0.056^{*} \\
(0.032)\end{array}$ & - & $\begin{array}{c}-0.081^{\star *} \\
(0.036)\end{array}$ & $\begin{array}{c}-0.082^{* *} \\
(0.041)\end{array}$ & - \\
\hline $\begin{array}{l}\text { Specification } \\
\text { Bandwidth } \\
\text { Manip. Test } p>|t|\end{array}$ & $\begin{array}{c}\text { Linear } \\
\text { msecomb2 } \\
0.9519\end{array}$ & $\begin{array}{c}\text { Linear } \\
\text { msetwo }\end{array}$ & $\begin{array}{l}\text { Linear } \\
\text { Msetwo }\end{array}$ & $\begin{array}{c}\text { Quad. } \\
\text { msecomb2 }\end{array}$ & $\begin{array}{l}\text { Quad. } \\
\text { msetwo }\end{array}$ & $\begin{array}{l}\text { Quad. } \\
\text { msetwo }\end{array}$ \\
\hline N. Obs. & 1,135 & 1,135 & 2,663 & 2,673 & 2,673 & 2,663 \\
\hline
\end{tabular}

related deaths. This shows that the execution of such policy is effective, since the mandatory nature of improvements in urban infrastructure associated with the renovation or construction of housing through RHP improves the quality of life and the health status of the inhabitants of municipalities covered by the program.

Table 6 displays the heterogenous response results. We observe through the regressions that the program was able to reduce deaths from sanitationrelated diseases due to the mandatory complement that it promotes, namely, the improvement in basic sanitation infrastructure, which can be observed through the regressions. This ensures that locations covered by the program have their structural conditions improved, which ends up affecting the number of deaths from sanitation-related diseases.

Now, we should check the robustness of our model to guarantee that our results are statistically unbiased and that our empirical strategy is correct.

Returning to Tables 4 and 5, we observe in columns 3 and 6 that the results were not statistically significant, what was expected given that those results come from effects in years prior to the beginning of the program and guarantees that potential previous factors do not affect the results we found. Still in Tables 4 and 5, it is possible to confirm that, even changing the specification and the bandwidth, the results keep indicating an effect of reduction of deaths.

The next Table to be analyzed is Table 7, which displays the results of the regression when we consider different cutoff points. The cutoff specified in the program is of 100,000 inhabitants; in these regressions, we changed it to two different false cutoffs $(105,000$ and 95,000$)$ and expected that the results would not be statistically significant. Indeed, we observe in the Table that for neither of the false cutoffs the results were significant.

Table 8 checks if the covariates included in our model have any statistical impact in it, what should be refuted. As a result, we observe that no statistically significant relationship was found for the covariates (public expenditure 
Table 6: Effect of the RHP on sanitation infrastructure.

\begin{tabular}{l|c|c|c|c}
\hline & $\mathbf{( 1 )}$ & $(2)$ & $(3)$ & $(4)$ \\
\hline$R H P_{t}$ & $0.642^{*}$ & $0.719^{* *}$ & $0.880^{* *}$ & $0.934^{* *}$ \\
& $(0.346)$ & $(0.370)$ & $(0.425)$ & $(0.431)$ \\
& & & & \\
& $0.821^{* *}$ & $0.824^{* *}$ & $0.969^{* *}$ & $1.014^{*}$ \\
& $(0.402)$ & $(0.418)$ & $(0.472)$ & $(0.509)$ \\
& & & & \\
$R H P_{t+1}$ & $0.667^{*}$ & $0.646^{*}$ & $0.655^{*}$ & $0.526^{* *}$ \\
& $(0.370)$ & $(0.372)$ & $(0.371)$ & $(0.258)$ \\
Specification & Linear & Linear & Quad & Quad \\
Bandwidth & msecomb2 & Msetwo & msecomb2 & msetwo \\
Controls & Sim & Sim & Sim & Sim \\
\hline N. Obs. & 4,793 & 4,965 & 4,775 & 4,947 \\
\hline
\end{tabular}

Note: Dependent variable: Ln sanitation infrastructure. All

specifications use a triangular kernel function. RHP estimates the discontinuity in municipalities right above the cutoff point $(100,000$ inhabitants). Robust standard errors are in parentheses. ${ }^{* *}=\mathrm{p}<0.01$, ${ }^{* *}=\mathrm{p}<0.05$, and $^{*}=\mathrm{p}<0.1$

Table 7: Robustness Test: Effect of the RHP on deaths from sanitation-related diseases - with changes in the cutoff point.

\begin{tabular}{|c|c|c|c|c|}
\hline & (1) & (2) & (3) & (4) \\
\hline \multicolumn{5}{|c|}{ Panel A: Cutoff change to 105,000 inhabitants } \\
\hline$R H P_{t}$ & $\begin{array}{l}-0.076 \\
(0.095)\end{array}$ & $\begin{array}{c}-0.042 \\
(0.088)\end{array}$ & $\begin{array}{c}-0.052 \\
(0.065)\end{array}$ & $\begin{array}{l}-0.052 \\
(0.065)\end{array}$ \\
\hline$R H P_{t+1}$ & $\begin{array}{l}-0.061 \\
(0.042)\end{array}$ & $\begin{array}{l}-0.058 \\
(0.042)\end{array}$ & $\begin{array}{l}-0.047 \\
(0.051)\end{array}$ & $\begin{array}{c}-0.047 \\
(0.051)\end{array}$ \\
\hline$R H P_{t \geq+2}$ & $\begin{array}{l}-0.026 \\
(0.029)\end{array}$ & $\begin{array}{l}-0.035 \\
(0.026)\end{array}$ & $\begin{array}{c}0.006 \\
(0.040)\end{array}$ & $\begin{array}{c}0.009 \\
(0.039)\end{array}$ \\
\hline \multicolumn{5}{|c|}{ Panel B: Cutoff change to 95,000 inhabitants } \\
\hline$R H P_{t}$ & $\begin{array}{l}-0.105 \\
(0.271)\end{array}$ & $\begin{array}{l}-0.098 \\
(0.280)\end{array}$ & $\begin{array}{c}-0.173 \\
(0.181)\end{array}$ & $\begin{array}{c}-0.153 \\
(0.196)\end{array}$ \\
\hline$R H P_{t+1}$ & $\begin{array}{l}-0.188 \\
(0.159)\end{array}$ & $\begin{array}{l}-0.206 \\
(0.171)\end{array}$ & $\begin{array}{c}-0.342 \\
(1.063)\end{array}$ & $\begin{array}{c}-0.423 \\
(1.078)\end{array}$ \\
\hline$R H P_{t \geq+2}$ & $\begin{array}{l}-0.147 \\
(0.105)\end{array}$ & $\begin{array}{l}-0.126 \\
(0.110)\end{array}$ & $\begin{array}{l}-0.048 \\
(0.461)\end{array}$ & $\begin{array}{l}-0.047 \\
(0.459)\end{array}$ \\
\hline $\begin{array}{l}\text { Specification } \\
\text { Bandwidth } \\
\text { Controls }\end{array}$ & $\begin{array}{c}\text { Linear } \\
\text { msecomb2 } \\
\text { Sim }\end{array}$ & $\begin{array}{l}\text { Linear } \\
\text { Msetwo } \\
\text { Sim }\end{array}$ & $\begin{array}{c}\text { Quad } \\
\text { msecomb2 } \\
\text { Sim }\end{array}$ & $\begin{array}{c}\text { Quad } \\
\text { msetwo } \\
\text { Sim }\end{array}$ \\
\hline
\end{tabular}

Note: Dependent variable: Ln Sanitation-related deaths. All

specifications use a triangular kernel function. Robust standard errors are in parentheses. ${ }^{* *}=\mathrm{p}<0.01$, $^{* *}=\mathrm{p}<0.05$, and ${ }^{*}=\mathrm{p}<0.1$. 
on ambulatory costs, hospital costs, and wages of civil servants in the health sector).

Table 8: Robustness Test: Effect of the RHP on deaths from sanitation-related diseases - with covariates.

\begin{tabular}{|c|c|c|c|c|}
\hline & (1) & (2) & (3) & (4) \\
\hline Ambulatory Costs & $\begin{array}{c}0.00012 \\
(0.00027)\end{array}$ & $\begin{array}{c}0.00011 \\
(0.00027)\end{array}$ & $\begin{array}{c}0.00018 \\
(0.00025)\end{array}$ & $\begin{array}{c}0.00018 \\
(0.00025)\end{array}$ \\
\hline Hospital Costs & $\begin{array}{c}-415.57 \\
(389)\end{array}$ & $\begin{array}{c}-412.41 \\
(389)\end{array}$ & $\begin{array}{l}-216.67 \\
(614.57)\end{array}$ & $\begin{array}{l}-165.64 \\
(600.44)\end{array}$ \\
\hline Civil Servant Wages & $\begin{array}{l}-5,900 \\
(3,600)\end{array}$ & $\begin{array}{l}-6,000 \\
(3,600)\end{array}$ & $\begin{array}{l}-8,700 \\
(5,400)\end{array}$ & $\begin{array}{l}-3,900 \\
(3,000)\end{array}$ \\
\hline $\begin{array}{l}\text { Specification } \\
\text { Bandwidth } \\
\text { Controls }\end{array}$ & $\begin{array}{c}\text { Linear } \\
\text { msecomb2 } \\
\text { Sim }\end{array}$ & $\begin{array}{l}\text { Linear } \\
\text { Msetwo } \\
\text { Sim }\end{array}$ & $\begin{array}{c}\text { Quad } \\
\text { msecomb2 } \\
\text { Sim }\end{array}$ & $\begin{array}{l}\text { Quad } \\
\text { msetwo } \\
\text { Sim }\end{array}$ \\
\hline
\end{tabular}

To complete our robustness tests, we changed the kernel function of our estimations from Triangular to Epanechnikov (Table 9) and Uniform (Table 10). In Table 9, the effects were the same as the ones found in Table 4, which was expected, diagnosing that the model and its results are robust to changes in the kernel function.

Table 9: Robustness Test: Effect of the RHP on deaths from sanitation-related diseases - changing the kernel function from Triangular to Epanechnikov.

\begin{tabular}{|c|c|c|c|c|c|c|}
\hline & (1) & (2) & (3) & (4) & (5) & (6) \\
\hline$R H P_{t}$ & $\begin{array}{l}-0.032 \\
(0.032)\end{array}$ & $\begin{array}{l}-0.043 \\
(0.033)\end{array}$ & $\begin{array}{l}-0.011 \\
(0.031)\end{array}$ & $\begin{array}{l}-0.056 \\
(0.042)\end{array}$ & $\begin{array}{l}-0.048 \\
(0.048)\end{array}$ & $\begin{array}{c}0.014 \\
(0.060)\end{array}$ \\
\hline$R H P_{t+1}$ & $\begin{array}{c}-0.095^{* *} \\
(0.041)\end{array}$ & $\begin{array}{c}-0.095^{* *} \\
(0.047)\end{array}$ & - & $\begin{array}{c}-0.093^{* *} \\
(0.042)\end{array}$ & $\begin{array}{c}-0.097^{* *} \\
(0.051)\end{array}$ & - \\
\hline$R H P_{t \geq+2}$ & $\begin{array}{c}-0.066^{* *} \\
(0.034)\end{array}$ & $\begin{array}{l}-0.063^{*} \\
(0.037)\end{array}$ & - & $\begin{array}{c}-0.076^{* *} \\
(0.033)\end{array}$ & $\begin{array}{c}-0.087^{* *} \\
(0.036)\end{array}$ & - \\
\hline $\begin{array}{l}\text { Specification } \\
\text { Bandwidth } \\
\text { Controls }\end{array}$ & $\begin{array}{l}\text { Linear } \\
\text { msecomb2 } \\
\text { Sim }\end{array}$ & $\begin{array}{l}\text { Linear } \\
\text { msetwo } \\
\text { Sim }\end{array}$ & $\begin{array}{l}\text { Linear } \\
\text { Msetwo } \\
\text { Sim }\end{array}$ & $\begin{array}{l}\text { Quad. } \\
\text { msecomb2 } \\
\text { Sim }\end{array}$ & $\begin{array}{l}\text { Quad. } \\
\text { msetwo } \\
\text { Sim }\end{array}$ & $\begin{array}{l}\text { Quad. } \\
\text { msetwo } \\
\text { Sim }\end{array}$ \\
\hline N. Obs. & 1,135 & 1,135 & 2,663 & 2,673 & 2,673 & 2,663 \\
\hline
\end{tabular}

Note: Dependent variable: Ln Sanitation-related deaths. All specifications use a Epanechnikov kernel function. RHP estimates the discontinuity in municipalities right above the cutoff point $\left(100,000\right.$ inhabitants). Robust standard errors are in parentheses. ${ }^{* *}=\mathrm{p}<0.01,{ }^{* *}=\mathrm{p}<0.05$, and $^{*}=\mathrm{p}<0.1$.

Table 10 shows the results with the kernel function changed from Triangular to Uniform. The results remained statistically significant and show that 
RHP does reduce the number of deaths from sanitation-related diseases.

Table 10: Robustness Test: Effect of the RHP on deaths from sanitation-related diseases - changing the kernel function from Triangular to Uniform.

\begin{tabular}{l|c|c|c|c|c|c}
\hline & $\mathbf{( 1 )}$ & $\mathbf{( 2 )}$ & $\mathbf{( 3 )}$ & $\mathbf{( 4 )}$ & $\mathbf{( 5 )}$ & $\mathbf{( 6 )}$ \\
\hline$R H P_{t}$ & -0.004 & -0.054 & -0.014 & -0.068 & -0.075 & -0.010 \\
& $(0.029)$ & $(0.036)$ & $(0.040)$ & $(0.048)$ & $(0.048)$ & $(0.043)$ \\
$R H P_{t+1}$ & $-0.088^{* *}$ & $-0.088^{* *}$ & - & $-0.073^{*}$ & $-0.079^{*}$ & - \\
& $(0.046)$ & $(0.046)$ & & $(0.047)$ & $(0.045)$ & \\
& & & & & & \\
$R H P_{t \geq+2}$ & $-0.087^{* * *}$ & $-0.072^{* * *}$ & - & $-0.064^{* *}$ & $-0.060^{*}$ & - \\
& $(0.028)$ & $(0.028)$ & & $(0.033)$ & $(0.033)$ & \\
Specification & Linear & Linear & Linear & Quad. & Quad. & Quad. \\
Bandwidth & msecomb2 & msetwo & Msetwo & msecomb2 & msetwo & msetwo \\
Controls & Sim & Sim & Sim & Sim & Sim & Sim \\
\hline N. Obs. & 1,135 & 1,135 & 2,663 & 2,673 & 2,673 & 2,663 \\
\hline
\end{tabular}

Note: Dependent variable: Ln Sanitation-related deaths. All specifications use a Uniform kernel function. RHP estimates the discontinuity in municipalities right above the cutoff point (100.000 inhabitants). Robust standard errors are in parentheses. ${ }^{* *}=\mathrm{p}<0.01,{ }^{* *}=\mathrm{p}<0.05$, and $^{*}=\mathrm{p}<0.1$.

In short, the results indicate a reduction in the number of deaths from sanitation-related diseases in the treated municipalities, that is, municipalities that benefit from the Rental Housing Program. They also indicate that this reduction persists over time.

We also verified that improvements in housing units in the municipalities covered by the RHP are accompanied by improvements in sanitation infrastructure, which extrapolates the major objectives of the program (related to mitigating the housing shortage) and shows that it is extremely effective in reducing the occurrence of diseases related to poor housing and sanitation conditions and poverty.

It is also important to reinforce the idea that, with the reduction of health issues related to sanitation, we also reduce the economic costs of treatments in hospitals and health institutions (costs with hospital admissions, tests and appointments), enabling an optimal resource allocation in situations and places with more urgent needs. This question has also been discussed by (Santiago 2018), (Araujo et al. 2013) and (Lavinas 2007).

Hence, verifying that the social impact of a public policy is broad and positive generates incentives for its expansion and consolidation in other regions.

\section{Final Considerations}

This paper analyzed the effect of the Brazilian Rental Housing Program (RHP) on the number of deaths from sanitation-related diseases. The global scenario shows us that poor housing conditions and housing shortage promote a radical deterioration of living conditions. An insalubrious environment is a sine qua non for generating diseases that become epidemics.

Given this pandemic condition, the federal government must be the actor in charge of controlling and managing the quality of life of its popula- 
tion, proposing and executing actions and programs that improve living conditions.

In some situations, the programs may have outcomes broader than those specified in their objectives. That was the case of the RHP, where we observed a reduction in the number of deaths from sanitation-related diseases, given that, besides the housing policy itself, it also improved basic sanitation infrastructure in the covered regions.

It is worth mentioning that the effect of the RHP occurs in a time horizon, which is evident when we observe that a statistically significant reduction of $11 \%$ in the number of deaths from sanitation-related diseases only occurs one year after the implementation of the program, since construction works demand time to be finished after the funds are released.

In statistical terms, we guarantee causality through a regression discontinuity design model and through heterogeneous response and robustness tests discussed in our empirical strategy and applied to the statistics of the study.

We conclude, then, that the RHP does reduce deaths from sanitation-related diseases and must be seen as an effective policy that improves living conditions and makes public management more efficient in terms of prophylactic measures.

\section{References}

Angrist, J. D. \& Pischke, J. S. (2008), Mostly harmless econometrics: An empiricist's companion, Princeton university press.

Araujo, J. M., Amaral Alves, J. \& Nóbrega Besarria, C. (2013), 'O impacto dos gastos sociais sobre os indicadores de desigualdade e pobreza nos estados brasileiros no período de 2004 a 2009', Revista de Economia Contemporânea 17(2).

Bonates, M. F. (2008), 'O Programa de Arrendamento Residencial - PAR: acesso diferenciado à moradia e à cidade', Risco Revista de Pesquisa em Arquitetura e Urbanismo (Online) (7), 147-164.

Cairncross, S., Bartram, J., Cumming, O. \& Brocklehurst, C. (2010), 'Hygiene, sanitation, and water: what needs to be done?', PLoS Med 7(11), e1000365.

Calonico, S., Cattaneo, M. D., Farrell, M. H. \& Titiunik, R. (2017), 'rdrobust: Software for regression-discontinuity designs', The Stata Journal 17(2), 372404.

Ekane, N., Weitz, N., Nykvist, B., Nordqvist, P. \& Noel, S. (2016), Comparative assessment of sanitation and hygiene policies and institutional frameworks in Rwanda, Uganda and Tanzania, Stockholm Environment Institute.

Fujiwara, T. (2015), 'Voting technology, political responsiveness, and infant health: evidence from Brazil', Econometrica 83(2), 423-464.

Gleick, P. H. et al. (2002), Dirty-water: estimated deaths from water-related diseases 2000-2020, Citeseer. 
Heller, L. (2009), 'Water and sanitation policies in Brazil: historical inequalities and institutional change', Water and Sanitation Services: public policy and management pp. 321-337.

Hutton, G., Haller, L. \& Bartram, J. (2007), 'Global cost-benefit analysis of water supply and sanitation interventions', Journal of water and health 5(4), 481-502.

Imbens, G. W. \& Lemieux, T. (2008), 'Regression discontinuity designs: A guide to practice', Journal of econometrics 142(2), 615-635.

Instituto Brasileiro de Geografia e Estatística - IBGE (2019), 'Atlas de saneamento'.

URL: www.ibge.gov.br/home/estatistica/populacao/atlas_saneamento/default _zip.shtm

Jiménez, A., LeDeunff, H., Giné, R., Sjödin, J., Cronk, R., Murad, S., Takane, M. \& Bartram, J. (2019), 'The enabling environment for participation in water and sanitation: A conceptual framework', Water 11(2), 308.

Lavinas, L. (2007), 'Gasto social no Brasil: programas de transferência de renda versus investimento social', Ciência E Saúde Coletiva 12(6), 1463-1476.

Lewin, S., Norman, R., Nannan, N., Thomas, E. \& Bradshaw, D. (2007), 'Estimating the burden of disease attributable to unsafe water and lack of sanitation and hygiene in South Africa in 2000', South African Medical Journal 97(8), 755-762.

Mara, D., Lane, J., Scott, B. \& Trouba, D. (2010), 'Sanitation and health', PLoS Med 7(11), e1000363.

McMichael, A. J. (2000), 'The urban environment and health in a world of increasing globalization: issues for developing countries', Bulletin of the world Health Organization 78, 1117-1126.

Mendonça, M. J. C. \& Motta, R. S. (2005), 'Saúde e saneamento no brasil'.

Ministério das Cidades - MC (2018), 'Programa arrendamento residencial'.

URL: www.cidades.gov.br.

Monasterio, L. (2013), O FPM ea estranha distribuição da população dos pequenos municípios brasileiros, Technical report, Texto para Discussão.

Montgomery, M. A. \& Elimelech, M. (2007), 'Water and sanitation in developing countries: including health in the equation'.

Nishimura, F. (2020), 'Efeito da habitação sobre a mortalidade infantil: Evidências de um desenho de regressão descontínua', Análise Econômica 38(76).

Nishimura, F., Freitas, C. E. d. \& Almeida, R. (2018), 'Impacto do financiamento habitacional sobre o mercado de trabalho na construção civil', Revista Brasileira de Economia 72(4), 497-514.

Organização das Nações Unidas - ONU (2019), 'Os 17 objetivos do desenvolvimento sustentável'.

URL: https://www.nacoesunidas.org/ 
Prüss, A., Kay, D., Fewtrell, L. \& Bartram, J. (2002), 'Estimating the burden of disease from water, sanitation, and hygiene at a global level.', Environmental health perspectives 110(5), 537-542.

Santiago, G. d. R. (2018), Impacto da cobertura de saneamento básico na incidência de doenças e nos gastos com saúde pública no estado do Rio Grande do Norte, B.S. thesis, Universidade Federal do Rio Grande do Norte.

Smith, A. C. (2016), 'Spring forward at your own risk: Daylight saving time and fatal vehicle crashes', American Economic Journal: Applied Economics 8(2), 65-91.

Teixeira, J. C., Oliveira, G. S., Viali, A. M. \& Muniz, S. S. (2014), 'Estudo do impacto das deficiências de saneamento básico sobre a saúde pública no Brasil no período de 2001 a 2009', Engenharia Sanitária e Ambiental 19(1), 8796.

Wolf, J., Johnston, R., Hunter, P. R., Gordon, B., Medlicott, K. \& Prüss-Ustün, A. (2019), 'A faecal contamination index for interpreting heterogeneous diarrhoea impacts of water, sanitation and hygiene interventions and overall, regional and country estimates of community sanitation coverage with a focus on low-and middle-income countries', International journal of hygiene and environmental health 222(2), 270-282.

Zucchi, P., Del Nero, C. \& Malik, A. M. (2000), 'Gastos em saúde: os fatores que agem na demanda e na oferta dos serviços de saúde', Saúde e Sociedade 9, 127-150.

\section{Appendix A}


Table A.1: ANNEX - Description of sanitation-related diseases.

\begin{tabular}{c|l}
\hline ICD-10 & \multicolumn{1}{|c}{ Description } \\
\hline A00 & Cholera \\
A01 & Typhoid and paratyphoid fevers \\
A02 & Other salmonella infections \\
A03 & Shigellosis \\
A04 & Other bacterial intestinal infections \\
A06 & Amebiasis \\
A07 & Other protozoal intestinal diseases \\
A08 & Viral and other specified intestinal infections \\
A09 & Infectious gastroenteritis and colitis, unspecified \\
A27 & Leptospirosis \\
A71 & Trachoma \\
A90 & Dengue fever \\
A91 & Dengue hemorrhagic fever \\
A95 & Yellow fever \\
B15 & Acute hepatitis A \\
B35 & Dermatophytosis \\
B36 & Other superficial mycoses \\
B50 & Plasmodium falciparum malaria \\
B51 & Plasmodium vivax malaria \\
B52 & Plasmodium malariae malaria \\
B53 & Other specified malaria \\
B54 & Unspecified malaria \\
B55 & Leishmaniasis \\
B57 & Chagas' disease \\
B65 & Schistosomiasis (bilharziasis) \\
B68 & Taeniasis \\
B69 & Cysticercosis \\
B71 & Other cestode infections \\
B74 & Filariasis \\
H10 & Conjunctivitis \\
\hline Note: Ad & ped from Teixeira al. (2014) and ID-10.
\end{tabular}

Note: Adapted from Teixeira et al. (2014) and ICD-10. 
